\title{
Export Standards, Market Institutions and Smallholder Farmer Exclusion from Fresh Export Vegetable High Value Chains: Experiences from Ethiopia, Kenya and Zambia
}

\author{
Julius J. Okello (Corresponding Author) \\ University of Nairobi, P.O. Box 29053, Nairobi, Kenya \\ Tel: 254-727-869-515Ｅ-mail: jjokello@gmail.com
}

Clare A. Narrod

International Food Policy Research Institute

2033 K St. NW, Washington, D.C., USA

E-mail: c.narrod@cgiar.org

Devesh Roy

International Food Policy Research Institute

2033 K St. NW, Washington, D.C., USA

E-mail: c.narrod@cgiar.org

Received: December 27, 2010 Accepted: January 21, $2011 \quad$ Published: December 1, 2011

doi:10.5539/jas.v3n4p188

URL: http://dx.doi.org/10.5539/jas.v3n4p188

\begin{abstract}
Many African countries are diversifying exports into fresh export vegetables, grown mainly by smallholder farmers. However, markets for these new products have stringent safety standards. This paper examines the green bean high value chain (HVC) for African exports to Europe to identify the critical points at which exporters strictly enforce buyers' quality requirements and the risk of exclusion of family farmers at these points. It then discusses the strategies African countries have used to get-around these challenges and maintain participation of some farmers. The paper identifies six critical control points but finds that farmers are most threatened with exclusion from green bean $\mathrm{HVC}$ at the farm-level and collection-centre control points. To overcome effects of these control points, study countries used two non-market strategies namely, collective action and public-private partnerships. These findings imply that the market, if left on its own, could adopt solutions that exclude smallholder farmers from export HVC.
\end{abstract}

Keywords: Family farmers, European food standards, Exclusion, Africa

\section{Introduction}

The past few decades have seen substantial changes in the kinds of agricultural exports and how export products are produced and marketed by many developing countries. Many African countries have recently diversified their exports into the production of non-traditional agricultural products. Many are aided by highland altitudes that enable the growth of cool season crops year-round and make it possible for these countries to meet year-round demands for produce by major European retailers (Singh, 2002; Okello, 2005). Most of the non-traditional crops in Africa are produced, mainly by smallholder (i.e., family) farmers, for exports to the European market. South Africa, Cote d'Ivoire, Morocco, Egypt and Kenya are leaders with leading exports being green beans. Many southern African countries have, in recent years, been diversifying into non-traditional exports as well. Over the last decade Zambia, Madagascar and Zimbabwe achieved rapid growth in fresh vegetables exports. Mozambique and Malawi are currently considering pursuing the high value non-traditional export strategy as well. 
Concurrent with the increase in non-traditional high value exports in some African countries, there has been a heightened attention by consumers and governments in Europe on the safety of food grown and exported from developed countries (Narrod, Devesh, Okello, Avendano, Rich \&Thorat, 2009). The concern with food safety has resulted from several factors. First, globalization has led to sourcing of fresh produce from countries where systems of food safety control are weak. Second, as incomes have increased, the demand for safe food has also risen with consumers willing to pay more for lower risk of microbial contamination, pesticides, and other disease-causing substances. Third, improvements in technology have made it easier to measure contaminants in food and to document their impact on human health. Further, international food scares, including Salmonella and Listeria in fruits and vegetables and avian flu in poultry, have also played a role by making consumers and food industry regulators more aware of the risks associated with food safety problems (Freidberg, 2004). Thus developing country governments have revised food safety laws to protect consumers and farm-workers.

Major European retailers and their developing country suppliers have responded by also developing very stringent food safety protocols. Access by farmers to high value European retail markets (especially the supermarkets) is based on compliance with these, usually costly to implement, food safety protocols. At the same time, production of non traditional exports - especially fresh export vegetables - in developing countries is dominated by poor smallholder households not necessarily aligned to multinational supply chains (Dolan \& Humphrey, 2000; Reardon, 2000). These producers face four distinct problems: 1) how to produce safe food, 2) how to be recognized as producing safe food, 3 ) how to be competitive with larger producers with economies of scale in compliance with food safety requirements, 4) and how to identify cost-effective technologies for reducing risk (Narrod \& Rich, 2005).

Consequently many smallholder farmers have found it hard to maintain their participation in the high value chains (HVC) with some exiting. Indeed several studies have documented the difficulties smallholder farmers encounter in complying with European standards (Okello \& Swinton, 2007; Graffham, Karehu \& McGregor, 2009). Graffham (ibid) in particular predict continued exit by smallholder farmers due to high cost of compliance with food safety standards. However, none of these studies explain the areas (points) along the HVC at which smallholder farmers face the greatest risk of being excluded from the export business. Consequently it is not clear at what point in the fresh export value chain the smallholder farmers are most threatened by the European food safety standards. This paper therefore addresses three research questions: i) what are the major food safety control points in the value chain of non traditional fresh exports? ii) at what points along the value chain are the developing-country smallholder farmers at greatest risk of being marginalized by the standards? iii) what strategies have African countries used to overcome the exclusionary effect of food standards on smallholders at these critical control points?

Knowledge of the critical control points and the value chain segment at which they post the most threat to smallholder farmers is important for the design of policy interventions to keep smallholders in the lucrative non-traditional export business. At the same time, exclusion of smallholder farmers from $\mathrm{HVC}$ has major implications for poverty reduction in many developing countries (McCulloh \& Ota, 2002).

This paper focuses on green bean production in Kenya, Zambia and Ethiopia for export to EU markets. Green beans are among the most important fresh vegetables exported from developing countries. Also, green bean production has been predominantly in the hands of smallholder farmers in Africa. There are important variations among the three countries studied with regard to the impact of international food safety standards on smallholder farmers. Part of the difference is attributable to their time of entry in the export markets. Kenya has a long history in these export markets while Zambia and Ethiopia are fairly new to this market. Further, Kenya started exporting to EU and developing the infrastructure and institutions (involving smallholders) way before the standards were in place while Zambia and Ethiopia entered when the European food safety standards had already set in. Throughout this paper we adopt Kimenye's (1993) definition of smallholder farmers as those having up to 2 acres in Ethiopia and Kenya and up to 5 acres in Zambia.

The rest of the paper is organized as follows. Section 2 lays out the conceptual and empirical framework. Section 3 presents the food safety standards African countries are subject to and identifies the critical control points. Section 4 discusses the enforcement of standard at these points and areas where the pose greatest challenge to farmers while Section 5 concludes.

\section{Conceptual and Empirical Methods}

\subsection{Conceptual Framework}

This paper uses the transaction cost theory to assess the threats of European food safety standards (EFSS) on continued participation of smallholder farmers in green bean high value chain. The emergence of EFSS has 
resulted in development of networks of relationships aimed at coordinating procurement of beans from developing country sources (Fulponi, 2005). The development of close relationships can result in transaction dependency and opportunism, especially where the transaction needs specific assets or is characterized by uncertainty. The literature identifies four types of asset specificity namely; temporal, physical, human, and locational (Okello \& Swinton, 2007). Asset specificity can lead to market failure following ex-post opportunism from the party not investing in such assets. Where assets are lumpy, the smallholders are disadvantaged because of diseconomies of scale (Poulton, Doward \& Kydd, 2005). The disadvantage of the smallholders is exacerbated by the poor public infrastructure that aggravates the need for private provision (like unreliable electricity leading to need for private generators). Geographical dispersion of farmers further drives up costs of enforcing buyer requirements hence screening out some farmers.

Theoretically, a number of institutional mechanisms for integrating smallholder farmers into the HVC exist. First, smallholder farmers could orient their products to target markets that are less demanding by shifting from the demanding supermarket chain to the less stringent wholesale chain and domestic markets. Second, smallholders can, through collective action, invest jointly in lumpy/costly assets together hence take advantage of economies of scale and reduce per farmer costs of such investment. Third, public sector could partner with the private sector to help smallholders overcome the challenges of market requirements by investing on infrastructural requirements that are lumpy or have public good characteristics (training and extension, road, supply of safe water).

\subsection{Empirical Methods}

The information used in this paper was obtained through detailed interviews with various participants in the green bean HVC conducted between January and February 2006 in Zambia, Kenya and Ethiopia. The interviewees included smallholder farmers, farmer group leaders, horticultural industry association leaders, exporters, domestic green bean buyers, EU importers and EU supermarkets and certification companies. The interviews were supplemented with secondary information and data from household survey conducted in Kenya in 2004 by the lead author.

The interviews focused on a number aspects relating to compliance with EFSS. These included: physical facilities needed to comply, the cost of implementing the facilities, the establishment of traceability system, the certification of compliance with various kinds of EFSS, sources of capital used to meet the standards and the institutional arrangements for compliance. Evidence about these aspects was triangulated after detailed personal interviews with the various actors above.

\section{Food Safety Standards and the Critical Control Points in Green Bean Exports}

In order to identify segments of the value chain where smallholder farmers are most at risk of being marginalized by food safety standards, we discuss the requirements of EFSS on farmers at each segment/stage of the HVC involving smallholder farmers. The identification of these control points was based on the code of practices documents (i.e., food safety protocols) employed by major fresh vegetable exporters in the study countries to ensure compliance with EFSS, and complemented with discussions with exporters' agronomists, group technical assistant and also field observations. A given exporters' food safety protocol is based on the requirements of its destination market which include but often exceed the Global Good Agricultural Practices (GlobalGAP).

This study identified three value chains through which smallholder farmers market their beans namely, the supermarket chain, the continental European wholesale chain, and the domestic value chain. We however limit our discussion to the supermarket chain since it is within this chain that EFSS are strictly controlled (Singh, 2002; Jaffee, 2003). The requirements of the supermarket chain include changes in type and quality of inputs used in production of beans (usually to less toxic chemicals) and absence of pests and diseases prohibited by the importing countries. Green beans marketed through this chain must be third party certified as meeting standards (e.g., GlobalGAP, Tesco supermarket's Nature's Choice or Sainsburrys' supermarket's Farm to Fork). Which standard the farmer(s) obtain certification against depends on the market supplied. In addition, the beans must be accompanied by a phytosanitary certificate issued by a competent authority in the country of origin guaranteeing absence of prohibited pests.

In both Kenya and Zambia, and increasingly in Ethiopia, input supply, quality and usage as well as technical advice to the growers are all very closely monitored and coordinated by the exporters supplying to the supermarket chain. In particular, the amount (i.e., dosage) and kind of pesticide used, and the growth stage of the beans at which the pesticide are used is closely supervised by the exporters through well trained field staff usually referred to as technical assistant (TA). The TA allows only the use of pesticides authorized by the destination market. Consequently farmers that formerly used toxic pesticides have had to shift from them to safer 
pesticides (Okello \& Swinton, 2010). The shift to safer pesticides usually implies higher costs of pest and disease control since the new safer pesticides tend to be more expensive (Jaffee, 2003). The new safer pesticides are also often less effective/efficacious in controlling pests and diseases.

Handling and hygiene practices during the harvesting, grading and packing of green beans sold through the supermarket chain are also closely coordinated. In both Kenya and Zambia, exporters have adopted the developed-country process standards such as the hazard analysis and critical control points (HACCP), good manufacturing practices (GMP), and good agricultural practices (GAP). The GAP have, in Kenya and Zambia, been implemented at farm level by farmers supplying leading exporters and are carefully monitored under contract. In these two countries, meeting the GAP requires that growers have clearly labelled toilets, pesticide storage units, pesticide disposal pits, designated waste disposal points and facilities for washing hands on the farm and/or in the grading sheds. Leading exporters also closely monitor the quality of water and soils used for growing beans. Such exporters test the water and soil they and their outgrowers use twice a year for pathogens (especially Coli forms and Salmonella). For majority of smallholder farmers these requirements are too expensive owing to the large capital outlays involved.

The exporters also require that farmers keep records of the type and quality of inputs used. Thus each farmer must keep records relating to crop movement, pesticide stock movement and pesticide applicator's spraying activities and schedule. These records accompany green beans to the exporter's pack-house with duplicate copies, which are available to the exporter. Keeping majority of these records requires special skills and functional literacy, and is therefore a significant hurdle the illiterate and low-skilled farmers.

The harvesting practices closely monitored by the exporter mainly relate to the hygiene and aesthetic qualities. The farmers are required to wash their hands before the start of harvesting, to have a headscarf when harvesting and not to wear a perfume. They are also required to keep small children away from the bean plot during harvested. The beans must be harvested into clean crates, designated specifically for that exercise, as part of the hygiene requirements. Farmers must also ensure that the beans are not bruised during harvesting as part of compliance with physical quality attributes. Harvesting beans into specific crates is also intended to prevent cross-contamination of beans with pathogens. Farmers are required to buy their own crates. Smallholder farmers who can't afford such crates individually buy them collectively as a group through interlinked credit arrangement that allows the exporter to recover the credit from farmers' sales. The crate is kept at the collection centre from where farmers can borrow them as needed.

Another major requirement during harvesting is the possession of a hessian cooler, a simple structure made out of sacks/gunny bags and used for temporary storage of beans in the field. The crates, when filled with beans, must be kept under a moistened hessian cooler to protect the beans from the harsh tropical heat. There are hygiene-related specifications regarding the location of the hessian cooler in the field and/or how the crates of beans ought to be stored. Farmers are required to locate hessian cooler away from toilets, manure/compost pits, and dusty roads or open/dusty grounds in order to reduce the likelihood of contamination with pathogens or dirt. These field-level postharvest handling practices are standard procedures in both Kenya and Zambia, but are less strictly enforced in Ethiopia. In Ethiopia, farmers are allowed to keep the beans under a tree shade. However, this happens because the beans from Ethiopia are sold through the wholesale market chains.

The transportation of beans from the field to the collection point/center is also tightly controlled, with control tightest in Zambia. The crates of beans are normally transported from the field to the collection point in crates using bicycles and ox-carts in Kenya and trucks in Zambia. The food safety (hygiene) requirements farmers must comply with during the transportation stage include covering the crates with clean dry material (i.e., cloth or paper) to keep off dust and dirt, and also to screen off the direct sunlight. Farmers must also ensure that the transport medium (ox-cart or truck) is thoroughly washed before the crates are loaded into it to prevent accidental contamination of beans with pathogens and dirt.

Once at the collection point, the beans are sorted and arranged into labelled crates. The grading shed within which sorting is done is required to have a cement floor, washable tables, crate store, facility for washing hands and an office for filing. The crates are labelled for traceability purposes with each farmer using crates bearing his/her unique identification. The crates must then be stored in a cool place awaiting collection by the exporter. The system used for storing beans at the collection points differ among the study countries. In Kenya, the beans are kept inside a charcoal cooler (with moistened charcoal) while farmers in Zambia use electricity-powered cold stores to chill the beans. In both cases, beans are kept at or just below room temperature, and the goal is minimize damage from tropical heat. In Ethiopia, farmers used makeshift collection points and had neither charcoal coolers nor cold rooms. 
Beans are transported from the collection centre to the exporter's pack-house in exporters' truck in Kenya or farmers' truck in Zambia. In both countries the trucks are non-refrigerated but usually take a short time from loading at the farm to off-loading at the pack-house. Same standards apply for farmer owned trucks as those for transport from the field to collection centre. That is, the trucks must be clean and covered.

The most careful attention to the control of contamination with pathogens occurs in the exporters' processing facilities (pack-houses). Leading exporters in both Zambia and Kenya have invested in state-of-the-art equipments that wash (with chlorinated water) and chill the beans before packing. The workers wear special clothes and rubber boots in the pack-house and are required to wash hands at regular intervals or whenever changing a shift to avoid cross contamination of beans with pathogens. A leading export company in Kenya randomly takes swabs from workers' hands and tests them for pathogens. When the swab tests positive for pathogens, that worker is penalized. All containers used at various stages of the processing are colour-coded to avoid mixing and hence cross-contamination with pathogens. In addition to requiring strict adherence to hygiene during processing (sorting, chopping, and arranging into trays and pallets), packing and bar coding (in the case of high care pre-packed beans) are done under temperature-controlled conditions. Similar situation exists in the EU importers' warehouses except that there is not much processing done there, with the main activities being repackaging and bar-coding. While farmers are not typically involved at the pack-house stage, rejection of their produce for failure to meet physical or hygiene standards has direct effect on their continued participation in the market.

There are clear differences in the way exporters in three countries treat beans sourced from smallholder. In Zambia, there is intense focus on reducing chances of produce contamination in the field with exporters and farmers clearly aware that pathogens originating from the farm can be carried over to the market. In Kenya, on the other hand, more intense efforts at controlling pathogen contamination are at the pack-house where the produce is moved through state-of-the-art cleaning and decontaminating equipments.

In sum, there are six critical control points in the supermarket HVC namely preharvest field level activities, the harvest, transport from field to collection centre, the collection centre, transport from collection centre to pack-house, and the pack-house. The extent of the threat of exclusion to smallholders at each of these points varies depend on the nature and cost of investment required to meet the hygiene and pesticide residue standards.

\section{Enforcement of EFSS and Strategies for Smallholder Farmer Participation in High Value Chains}

\subsection{Enforcement and exclusionary tendencies of EFSS}

Enforcing the EFSS has led to tightly coordinated HVC for bean in both Kenya and Zambia. A tightly coordinated supply chain, however, works against the smallholder for three reasons (Rich \& Narrod, 2005): i) information asymmetry and transaction costs, ii) organizational constraints, and iii) regulatory failure. Indeed, as the chains have become more coordinated in the three study countries with the imposition of EFSS, it has created an entry barrier for the smallholders or has screened them away from the more safety-discerning high value chains notably some leading supermarkets. The exact number of smallholders that have been marginalized by the EFSS at each of the highlighted critical control points (CCPs) is not known. However, what occurred in Kenya following the introduction of EFSS provides some evidence on the screening effect of these standards. In Kenya, more than half of the smallholder outgrowers were dropped by leading exporters soon after the European retailers they supplied started demanding strict compliance with their private food safety protocols. Consequently, while smallholders in Kenya produced over $60 \%$ of green beans in 1980 s, their share had dropped to about $30 \%$ by 2003 (Kimenye, 1993; Jaffee, 2003).

The degree of exclusion of smallholder farmers has depended on the type of investments they are required to make to meet the food safety requirements at each of the critical control points highlighted above. At pre-harvest the field level CCP, individual smallholder farmers have found investment in facilities and skills needed to assure safety (i.e. hygiene and pesticide residue limits) unaffordable. Such investment include employing a technical assistant (whose work is to keep records needed to demonstrate traceability and also to advice on pesticide usage rates), constructing a pesticide storage unit and shifting to safer but often more costly pesticides. These investments are quite expensive as shown by Figure 1. Figure 1 also demonstrates that the collection centre CCP also poses a serious challenge to farmers in terms of cost of facilities required meet EFSS. Under this CCP farmers need to invest in a grading shed with cement floor and washable tables, a store for storing crates, filing office, pit latrine, charcoal cooler, and a facility for washing hands. Some exporters also require farmers to have waste disposal pit at the collection center.

In general, the tight control aimed at preventing produce contamination with pathogens and pesticides in the field, during transportation, and in the collection center points and the difficulties smallholder farmers have investing in facilities needed to meet requirements at each of these points worked against their continued participation in 
the high value chains. In all the three countries exporters shunned working with smallholder farmers, often keeping a few for ethical reasons (Dolan \& Humphrey, 2000). In Kenya, the enforcement of food safety standards at the critical controls points outlined above led major supermarket suppliers to abandon sourcing from smallholder farmers, instead integrating backwards to start up own estate farms (Dolan \& Humprey, 2000).

In Zambia, the first exporter (York Farms) initially sourced exclusively from own estate farms or from larger better off outgrowers because it doubted the ability of smallholder farmers to meet the EFSS. Small farmers began participating in the Zambian green bean business when Agriflora Limited, a fresh export vegetable exporter, entered the green bean export business. Agriflora had to undertake some of the activities that were critical for compliance with EFSS to assure its buyers that it was safe to work with smallholder farmers. Such activities included application of pesticides (done by team of pesticide applicators), dispensing the pesticides as needed (to ensure compliance with maximum residue limits), and keeping records (for traceability). Agriflora collapsed in 2004 (for reasons unrelated o to standards) leaving York Farms as the only green bean exporter. However, York Farms would not buy beans produced by the smallholders for fear of violation of hygiene and residue requirements (Narrod et al, 2009). Consequently smallholder farmers were forced to abandon production of green beans for European market in Zambia. Thus in the case of Zambia, EFSS screened $100 \%$ of the smallholder farmers from green bean export HVC.

In Ethiopian where smallholders grow $20 \%$ of green beans, the exporters undertake pesticide handing and application for the farmers just as Agriflora did in Zambia. The farmers' roles are limited to planting, weeding and harvesting the beans. These activities have no implication on the safety of beans hence pose no risk of pesticide residue or hygiene violations to Exporters. However, the exporters working with smallholders still face significant challenges in enforcing hygiene standards at the collection points.

\subsection{Strategies for maintaining smallholder participation in the supermarket chain}

The upshot of the above discussion is that farm-level EFSS requirements have had a strong screening effect on smallholders especially at the pre-harvest field and collection center CCPs. So how have some smallholder farmers managed to stay in fresh export HVC? Some smallholder farmers and the governments have adopted two non-market institutional arrangements for overcoming the screening effects of EFSS on smallholder farmers namely, collective action and public-private partnerships.

Smallholder industry in Kenya and Zambia responded to screening effect of EFSS through institutional innovation in form of collective action and public-private partnerships. As a group, smallholders invested in facilities needed to comply with EFSS at the major CCPs thus reducing their per-person costs of meeting EFSS. Similarly, smallholder farmers sought certification (especially for GlobalGAP) jointly in order to demonstrate compliance with EFSS, though mostly with external support from governments, private sector or partnership of the two (i.e., public-private partnerships).

Public-private partnerships (PPPs) for maintaining the participation of smallholder farmers in the green bean HVC have mainly focused on provision of information, financial support (for investment in lumpy assets), and capacity building (through financing audits and certification for GlobalGAP compliance and the construction of grading facilities) to smallholders. In Zambia, the partnership between Japan International Cooperation Agency (JICA) led to construction of cold stores at the collection centre thus meeting safety and hygiene the requirements of the collection center CCP. In Kenya, donors and NGO have jointly established Africa's only indigenous certification company (AfriCert) in order to make GlobalGAP certification cheaper and hence affordable to smallholders. In Kenya and Ethiopia, investment by some of the European private agencies (private sector) especially the Pesticide Initiative Project (PIP) helped in training farmers on pesticide use practices and pesticide residue limits thus helping reduce the screening effect of EFSS at farm-level CCPs. PPPs have also been instrumental in lobbying for the recognition of the ability of smallholders to meet GlobalGAP standards and the benchmarking of GlobalGAP to Kenyan conditions through the formulation of KenyaGAP.

\section{Conclusions and Policy Implications}

This paper identifies six critical points along the green bean HVC at which exporters enforce strict compliance with EFSS to avoid produce contamination with pathogens and pesticide residue. These are pre-harvest field level activities, harvest stage, transport from field to collection centre, the collection centre, transport from collection centre to pack-house, and the pack-house. Among these, the points at which smallholder farmers are most threatened with exclusion from HVC are pre-harvest field level and the collection centre control points. At these points the costs of investing in facilities needed to meet EFSS are too high for most smallholder farmers. Consequently a number of smallholder farmers have been screened off.

The study countries have used two non-market strategies to overcome the screening effect of EFSS smallholder farmers face at these critical control points namely, collective action and private-public partnerships. Through 
collective action smallholders have been able to jointly invest in the costly facilities while public-private partnership has enabled farmers to access training and achieve the third party certification needed to demonstrate compliance and overcome the screening effect of EFSS at the two most critical CCPs.

The implication of this study is that government, private sector and donor intervention in keeping smallholder farmers in the HVC should not ignore the field and collection centre control points. Although a number of investments at these levels are private, they involve lumpy investments that are too costly for smallholders. The study also implies that at the two most challenging control points, the market, if left on its own, could adopt solutions that marginalize smallholder farmers. Thus countries seeking to diversify exports by shifting to production of fresh export vegetable (usually produced by smallholder farmers), should be ready, on their own or jointly with the private sector, to invest in supporting smallholder farmers at the two CCPs at which EFSS pose greatest challenge to such farmers. In addition, the findings of the study imply that governments should facilitate and, where necessary, support farmers to form producer organizations through which they can overcome the screening effects of EFSS. Obstacles such as long process of registering such organizations and registration fees should be reviewed to expedite the process of forming such farmer organizations.

\section{References}

Dolan, C. \& Humphrey, J. (2000). Governance and trade in Fresh vegetables: The impact of UK supermarkets on African horticultural industries. Journal of Development Studies, 35, 147-177.

Freidberg, S. (2004). French Beans and Food Scares: Culture and Commerce in an Anxious Age. Oxford University Press. New York

Fulponi, L. (2005). The globalisation of private standards and the agro-food system. Paper presented at the Pre-Conference Workshop at the European Association of Agricultural Economists Conference, The Future of Rural Europe in the Global Agri-Food System.

Graffham, A., Karehu, E., \& McGregor, J. (2009). Impact of GLOBALGAP on smallscale vegetable growers in Kenya. In Evaline B. de Battisti, James Mcgregor and Andrew Graffham (Eds) Standard Bearers: Horticultural Exports and Private Standards in Africa. Natural Resources Institute. London, UK.

Jaffee, S.M. (2003). From Challenge to Opportunity: The transformation of the Kenyan fresh vegetable trade in the context of emerging food safety and other standards. Agriculture and Rural Development Discussion Paper 1, World Bank. Washington, DC

Kimenye, L.N. (1993). Economics of Smallholder French Bean Production and Marketing in Kenya. PhD Dissertation, Michigan State University, USA.

McCulloh, N., \& Otta, M. (2002). Export horticulture and poverty in Kenya. IDS Working Paper 174. Institute of Development Studies.University of Sussex, UK.

Narrod, C.A., Devesh, R., Okello, J.J., Avendano, A., Rich, K.., \& Thorat, A. (2009). Role of public-private partnerships in ensuring smallholder participation in high valued fruit and vegetable supply chains. Food Policy, $34,8-15$

Okello, J.J., \& Swinton, S.M. (2010). From circle of poison to circle of virtue: Pesticides, export standards and Kenya's green bean farmers. Journal of Agricultural Economics.

Okello, J.J., \& Swinton, S.M. (2007). Compliance with international food safety standards in Kenya's green bean industry: Comparison of a small and a large scale family farm producing for export. Review of Agricultural Economics, 29, 269-285.

Poulton, C., Doward, A., \& Kydd, J., (2005). The future of small farms: New directions for services, institutions and intermediation. Paper prepared for the future of small farms workshop, 26-29 June 2005, Imperial College, Wye, UK.

Reardon, T., \& Farina, E. (2002). The rise of private food quality and safety standards: Illustrations from Brazil, International Food and Agricultural Management Review, 20, 317-334

Regmi, A., \& Gehlhar, M. (2005). Processed food trade pressured by evolving global supply chains. Amberwaves. February 2005 Issue. USDA/ERS. Washington DC.

Rich, K.M., \& Narrod, C.A. (2005). Perspectives on supply chain management of high value agriculture: The role of public-private partnerships in promoting smallholder access. Draft Concept. IFPRI. Washington DC

Singh, B.P. (2002). Nontraditional crop production in Africa for export. p. 86-92. In: J. Janick and A. Whipkey (eds.), Trends in new crops and new uses. ASHS Press, Alexandria, VA 


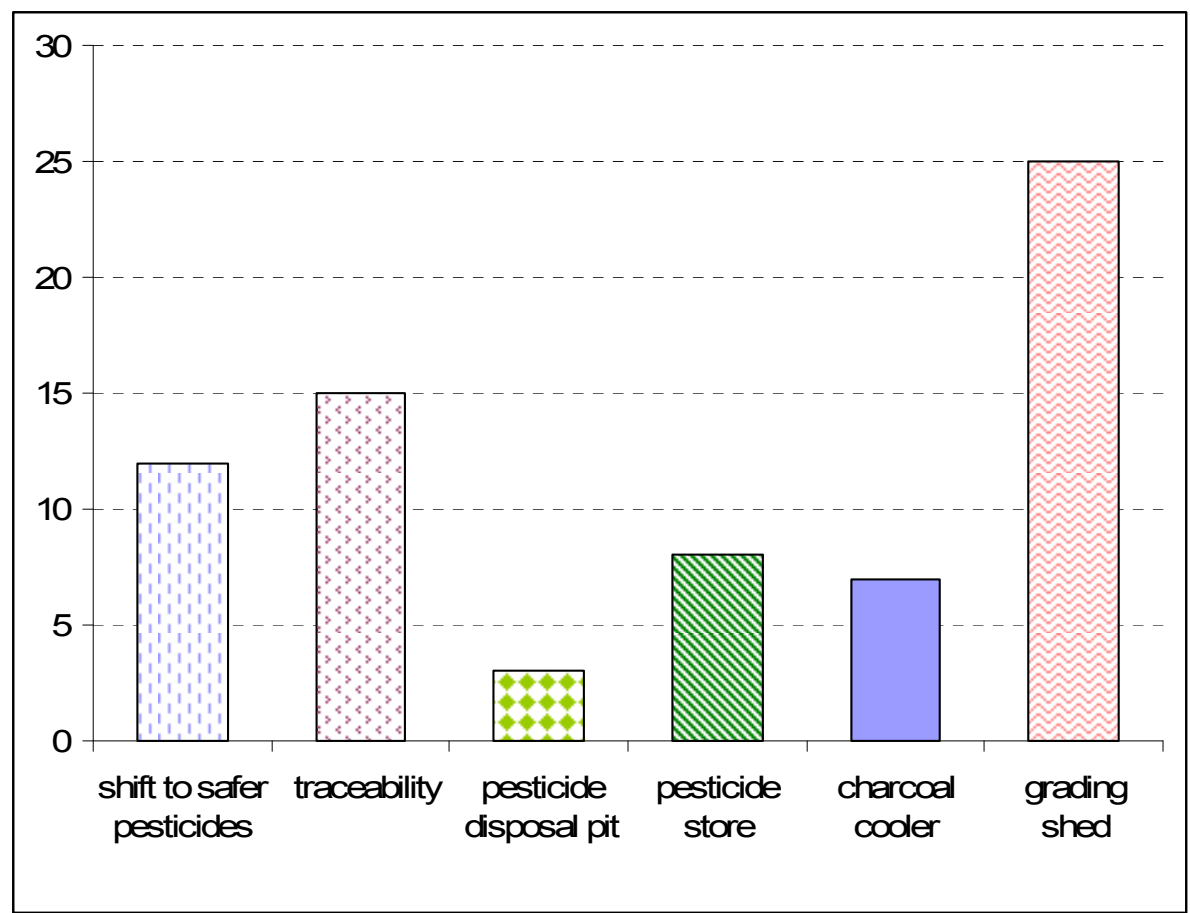

Figure 1. Cost ('000 Kenya Shilling) of complying with food safety standards in Kenya, 2005-2006 Figure showing the various costs of complying with European food safety standards. 